\title{
THE SWEET DRY FRUIT OF THE LOTUS TREE
}

I pedaled my bicycle faster and faster in small circles as the garbage truck edged toward our driveway. The men yelled over the noise as they jumped off the back, emptying trash cans into the rear loader, and our neighbor's chaise lounges and wicker chairs snapped and splintered, crushed with pizza boxes, soda cans, and meat wrappers. Flies swarmed, and stinking liquid dripped from the bottom of the truck. While the men took turns drinking from the neighbor's garden hose, I rode to the end of the driveway, jumped off my bike, and tossed it in. I hid in the garage and watched the red, white, and blue tassels of my handlebars flutter on the lip of the metal hopper and then disappear forever.

My family refers to my father's return to Iran as "when Baba got sick." Photographs from the mid-196os reveal a gaunt, dazed man, pale, thin, and hollow-cheeked. I was ten years old when my father left Providence only fifteen years after he'd arrived.

Baba sometimes said, "I don't know what I am anymore. I'm a foreigner in my own house." He claimed Persians viewed him as an American because he spoke Persian with an American accent, while Americans viewed him as a foreigner because he spoke English with a Persian accent. He was an Iranian Muslim, yet one of his closest friends was an Afghan Jew named Ted Nahdoli; they'd trained together at Brown and partnered in a cardiology practice.

The Sunday before, Dr. Nahdoli had shown up at the door just after dinner.

"Salam, Reza-Jon," Dr. Nahdoli said. "How is the apple of your Baba's eye?"

I blushed and looked down. "Salam, Agha Docteur. May I take your coat?" Baba taught me that all guests deserved special treatment. Dr. Nahdoli's cologne caused my eyes to water, and I sneezed. He handed me a handkerchief that matched the blue silk tucked in the breast pocket of his jacket. The cloth was soft and slippery. It glided through my fingers and onto the Persian carpet that had been my grandmother's in Esfahan.

"I can't blow my nose in this, Amu. It's too nice," I said as I stooped to pick it up.

Dr. Nahdoli didn't look much like Baba-he was shorter and heavier-but they both dressed formally in felt hats, leather gloves, and long, mothballscented coats. In English they had heavy accents, but in greeting each other 
they spoke Persian, a blend of sing-songy rhythms with rapid, guttural spurts of throat-clearing. Dr. Nahdoli said Persian was the official language of his Afghan tribe, and I pictured half-dressed Indians dancing around a blazing campfire in the dark wilderness. The men kissed, three kisses: one cheek, then the other, then back to the first.

As I struggled to hang Dr. Nahdoli's coat in the front closet, Baba raised his voice. I crept into my father's study, right off the foyer, and hid on the far side of the couch on all fours just as my mother escorted the two in. I strained to understand the Persian Baba had taught me. I could see their reflections in the glass covering his framed diplomas on the opposite wall.

"I have trouble sleeping, so maybe I take an injection now and then," my father said. He and Dr. Nahdoli always spoke just inches from each other's faces.

"Please don't embarrass yourself. You are Sayed Docteur Hamid Ali Esfahani, and you are disgracing yourself and your family."

Baba clicked his tongue against the roof of his mouth and raised his chin, a gesture my mother hated. "Why must you Afghans always exaggerate?"

"People are talking, Hamid," Dr. Nahdoli said. "I will not stand by idly while they take you to jail. You must give up your practice for now. Leave the country."

I thought of Baba's office, his pretty nurse, Marie Louise, and the painting of the Alborz Mountains covered in snow that hung above his desk. My mother wiped her eyes with a tissue. How dare this man threaten Baba. People looked up to my father, asking his advice and thanking him for saving their lives. I hated Dr. Nahdoli. It didn't matter how much I loved the gold Playboy ' 67 bike with the banana seat he had given me for my birthday.

Now I understood: the vials labeled Demerol on the vanity in the upstairs bathroom and on Baba's nightstand; the time I saw him zip up the drugs in a toilet kit and go out to his car. The next day, I had tried and failed to pick the lock of the glove compartment in our Impala with a bobby pin, like Robert Wagner in It Takes a Thief.

My sisters, Mitra and Farah, were just seven and two, and Jafar was a good older brother, but he was in seventh grade, and all he cared about was baseball and basketball. He never concerned himself with the problems of adults.

"Did you know that Grandma and Grandpa didn't want Mom to marry Baba?" I asked him once as we smacked each other with fly swatters in our grandmother's kitchen. "They thought he was too foreign and weird." 
"They're the weird ones, not him," Jafar said.

"It's because he was Muslim and she was Irish Catholic."

Jafar ducked as I swatted him. "I know. Who cares anyway?"

Since I didn't have a bike to ride to school anymore, I started walking, and for a week no one noticed. I thought I was busted when I rounded the garage after school and saw my mother sitting Persian-style, like a toddler, bent at the knees with her behind just an inch from the ground. I watched in silence as she lined up vials of Demerol and glass syringes on the cement slab that covered our septic system. She picked up the meat mallet that Baba used to tenderize lamb and smashed each one into powder.

When she saw me, she cried out, covering her face with both hands.

The night before, Baba had eaten alone after returning late from the hospital. The meat was tough and dry, so he started yelling. My mother shouted back. He threw his plate at the wall, shattering it, and a small, jagged piece landed in my hair. My father rolled up a sleeve as he walked toward the bathroom. I dove for his legs and wrapped myself around them. "Don't take those drugs, Baba!" I pleaded. He knelt on the floor and held me in his arms. His face felt like sandpaper against my cheek. I repeated what my mother often told me: "You have a family that loves you, Baba. You have a family that loves you. You have a family that loves you. Right, Mommy?" My mother said nothing.

I pulled the mallet from my mother's hand and hugged her from behind as she sat on the ground, her long red hair damp against my face.

"Where's your bike, Reza?" she asked.

"Stolen at school," I said.

We spent our summers on my grandfather's dairy farm in Stockbridge, Massachusetts. By the time I was ten, my brother and I were driving the tractors to free up the hired hands to work the hay wagons we pulled. It took all my strength to let out the clutch on the old Farmall. If I bucked the wagon, the men teased me. When Uncle Neil, my mother's brother, was working, I let him drive because he had a bad back from the War, and when it acted up he could barely walk, let alone toss bales. He was a wiry, muscular man with a shaved head and a limp. His blue eyes were vigilant, never resting, darting toward the slightest noise. On the days he drove, I worked alongside the men, shirtless and sweaty with hayseed sticking to my skin. My hands grew calloused, and my forearms got scratched from the cut straw on the sides of the bales, so heavy that I sometimes needed Jafar's help to lift them. Uncle 
Neil told us to hoist the bales by holding the twine that bound them, then to swing them like a pendulum. When enough momentum built up, a strong man could toss a bale up several tiers onto the wagon.

In the shade of an oak, we kept old Clorox jugs filled with ice water from the spring behind the creamery. I'd get so thirsty that I didn't mind when tobacco juice from the men's mouths rolled down the sides of the white plastic.

The summer after I found out about the Demerol, I was anxious to get back to Providence to see how Baba was doing. We had spent eight weeks away from him, "home on the farm." My mother called Stockbridge "home" throughout my childhood, one of her ways of insulting Baba.

He was thin and tired; he'd worked every day we were gone. My mother told him how we'd made our own peach ice cream, taking turns cranking the squeaky handle of the machine. "Their grandpa is so good to them," she said, looking out the kitchen window with a smile as she did the dishes, her wedding band clanking against the plates.

The next day Baba took us kids to the Newport Creamery on Smith Street. He pulled into the parking lot, stopped the car, and said he needed to rest before we went in. He fell asleep, and we couldn't wake him up.

"What's wrong with Baba?" Mitra asked.

Farah jumped up and down in the backseat. "Ice cream, Baba! Ice cream!" "He's just stoned," Jafar said.

"Stoned like St. Stephen at Sunday school?"

"What are you, Mitra, a retard?" Jafar said. "Not stoned as in throwing stones. Stoned as in stoned."

"He's sick," I said. "Let's get some ice cream." I reached into Baba's trousers pocket and found a ten-dollar bill.

We ate at a picnic table under a streetlight in silence. We all touched cones, mixing the flavors of strawberry, vanilla, and mint chocolate chip.

Back at the car, we couldn't move Baba, so I sat on his lap and drove. He intermittently stepped on the brake, causing the car to buck, and my sisters laughed that the car was dancing. By then, our parents slept separately, so Jafar and I carried our father up to his room. We lay on either side of him that night, wondering if he would still be able to fix people's hearts. Our mother did not check on us. In the morning, we snuck back to the room we shared.

After that night, I started chauffeuring Baba around. Sometimes he let me drive even when he wasn't stoned. I was tall for my age and could reach the pedals. I wore Baba's sunglasses and fedora, which I thought made me look 
older. Baba laughed and said I looked like a Mafia man. Jafar had gotten a new mini-bike for his birthday and felt car driving was less manly than riding the trails behind our house. The first time I drove Baba in daylight was to his lawyer's office. I didn't realize he was making his will.

The day before Baba left for Iran, he called me into his bedroom. I acted as if nothing special was happening. He had just showered and shaved, and he wore maroon silk pajama bottoms with a ribbed, white tank top.

"I need to go home to get better," Baba said.

"But, Baba, you are home."

"To my own country, where I can think clearly."

"But you're coming back, right?" He smelled of aftershave, minty and strong. My eyes watered and I sneezed.

"In your life," he said, "be a decent person." He pressed a twenty-dollar bill into my hand, then knelt on the carpet and pulled me into his arms.

I kissed his neck, buried my face in it, and sobbed. I didn't even care about the aftershave.

The next morning at dawn I was awakened by the low rhythmic hum of my uncles praying as they faced Mecca and recited verses from the Koran. They had come from Iran to take Baba away. They brought with them the fragrance of dried lemon and the stale scent of body odor. Baba said his brothers, like many in Iran, did not use deodorant.

"Salam, Amu Kambiz. Salam, Amu Bijan," I said as I kissed each man at breakfast.

"Ahh, Reza-Jon. You are nearly grown," Amu Bijan said. "Your father tells us you and Jafar will look after things while he is away."

"Yes, Amu, we will," I said, struggling to converse in Persian.

"And you will help Mitra-Jon with her schoolwork?"

"Yes, Amu."

"And you will help your mother with the baby?"

"Farah can walk now. She's not a baby anymore."

Jafar and I carried the luggage to the taxi that evening. Baba sat in the back between his brothers. Mitra and Farah blew kisses as Jafar saluted like a soldier. I thrust my chest forward, crossing my arms with my chin high, the way my father had done. He smiled at me through the car window. My mother did not come out of the house. 
I sent Baba newspaper clippings of the 1967 Red Sox season. In the summertime he had often roamed the house with a transistor radio to his ear, listening to the games. He threw the radios whenever the Sox were losing and once went through seven in a single season. I thought pictures of Carl Yastrzemski's great left-field catches that year in the World Series might convince him to come home.

After two months, my mother said she was going back to work as a dietician because we had run out of money. I vacuumed, did laundry, and cooked from recipes she left scribbled on old envelopes stuck to the refrigerator by magnets. I filled the Crock-Pot with onions, chickpeas, dried lemons, potatoes, and chunks of lamb.

Baba called once a week on Saturdays for a couple of months, and then the calls started to taper off until, after six months, nothing.

If I asked when Baba was coming home, my mother said, "Your guess is as good as mine."

"But is he okay?"

"How would I know?"

The next summer, Uncle Neil came to get us because my mother had to stay in Providence to work. The night before we left for Stockbridge, my mother and I were alone in the kitchen after dinner. I scrubbed the big frying pan as she sat at the table sipping wine. She had had an argument with her brother.

"Mommy, what's wrong?"

"Well, we have no money, I have no husband, and you have no father. Is that enough for you?"

"But you have a family that loves you," I said.

She put her head down and shook it. "Someday you'll understand, Reza."

I went to my mother and hugged her from behind, the hard back of the chair between us. She slipped from my arms and stood up so quickly I almost lost my balance.

"I'm going to the gas station to get some cigarettes," she said.

"But, Mom, you don't even smoke," I said as the screen door slammed.

When we got back to Providence at the end of that summer, there was still no word from Baba. Mom had met a man at work named Bob. He was pale, and he parked under the basketball hoop in the driveway when he knew we would be playing. In October, Jafar and I watched from an upstairs window 
as he tried to bury our mother in a pile of leaves, laughing so hard we saw the fillings in his molars.

One night, Jafar arranged a pick-up game with boys from the neighborhood, mostly Italian kids. It was so cold we could see our breath as we jumped for rebounds. The boys played under Baba's lights, passed the ball Baba had bought, and shot baskets into the hoop Baba had installed over the garage. I was guarding Ray Palazzo, who was shorter than me by a foot even though he was older. Ray leaned in close: "Een ma coontry we is a buncha monkeys and we eata much fruits." Baba had always dressed and put on a tie when the boys came over. He carved up apples, pears, and oranges, and offered slices on the edge of a knife. "In my country, we eat fruit like candy," he said. There were never any takers.

"What's so great about your parents?" I yelled at Ray. "My father came here with nothing, and now he's a cardiologist, and your father's a baggage handler at the airport!" I was repeating things I'd heard my mother say.

"Fruits iza like candies, and by the way, your father's not a cardiologist anymore because he's probably dead," Ray said.

I looked at Jafar.

He walked toward Ray. "Shut up, you idiot!"

"Why should I?" Ray said. "He's such a jerk he even lost his stupid banana bike. Fruits eez tasty!"

"Go home!" Jafar shouted. He ran after me into the house.

"Ray Palazzo said Baba's dead, Mom. He said Baba's dead."

"Don't listen to those silly boys," she said, standing at the kitchen sink.

"But when is Baba coming home?"

Thanksgiving and Christmas passed, and so did my birthday, but Baba's chair remained empty. My mother never let me drive.

"Don't be ridiculous, Reza," she said. "Eleven-year-olds who drive are committing a crime."

I bided my time until Nowruz, the Persian New Year, the first day of spring and Baba's favorite holiday. He said everyone got a fresh start on Nowruz. We always prepared for the holiday by cleaning the whole house, and then Baba would take us all out to buy new clothes. The way we behaved on Nowruz would predict how the coming year would pass.

"Mom, we have to make Nowruz just the way Baba does." 
"Whatever you say, Reza." She gave in and bought me a new sports jacket, a shirt, and a white belt with matching shoes like Baba's.

A few days before Nowruz, I laid out a special Persian tablecloth depicting a village scene with men farming and hunting, women cooking over campfires, and children playing with goats. Baba had brought it home after a summertime trip to Iran, and I loved the way the tassels on the edges of the fabric tickled my skin as I spread it onto the dining room table. I was making what Baba called the "Ceremonial Table of the Seven S's." The number seven was sacred in Iran, and so you had to put out seven items, all beginning with the letter Sinn, or $S$, which stood for the most important things in life: rebirth, health, happiness, prosperity, patience, beauty, and love. I arranged a head of garlic, bean sprouts, an apple, vinegar, pudding, and crushed sumac, but I couldn't remember the seventh item. It would all be ruined.

"Dr. Nahdoli would know," my mother said. "Give him a call."

"Never in a million years," I said.

Jafar counted the S's. "The fruit of the lotus tree," he said. "That's what's missing."

"We never had a tree on the table when Baba made it. I don't even know what a lotus tree is."

"It's a sweet, dry fruit. Just put out some apricots or prunes," Mom called from the kitchen. "That will work."

I got the carton of prunes from the pantry and scattered a few on a plate. Jafar added a mirror, a silver dollar, and a hyacinth our mother had bought for Easter - things we remembered Baba adding to the seven S's. We stepped back and surveyed the table. It felt like home, and I hoped it would bring Baba back.

I woke up early on Nowruz. Nobody else was up. I put tea in the antique china pot my parents got for their wedding and placed a bowl of sugar cubes next to the teacup. Persians like to put the little squares in their mouths and then suck the tea through them, a habit my mother had taken up. On a platter I arranged feta cheese, sliced cucumbers, almonds, and pita bread toasted crispy, the way Mom liked it. Using Baba's recipe, I prepared a side dish of yogurt with mint leaves, pepper, and grated onions and brought the tray to my mother's room.

She was sleeping. I set the breakfast on the nightstand and went to get the present I had bought for her with the allowance Baba used to give me on Saturdays. It was a dress with bright yellow flowers. I had borrowed 
Jafar's bike to go to town to buy it, but the saleslady sent me home to get a photo of my mother so she could estimate the size. The store had free giftwrapping. I asked Jafar and my sisters to sign the card, and Farah scribbled over everybody else's signature because she was too young to write her name, but I didn't get mad. When I got back to my mother's room she was awake, sipping the tea.

"Happy Nowruz, Mom."

"Happy New Year, Reza," she said. "You fixed everything just right."

"But I want this Nowruz to stay perfect," I said, handing her the box. "It's a dress. The lady at the store said it's cheerful."

"How sweet," my mother said as she opened it. She started to cry.

"It's supposed to make you happy, Mom."

"It does, honey. It does," she said, inspecting the dress as she held it up in front of her.

She went into the bathroom to try it on. When she came out she said, "It's a size too big."

She was right. The dress looked like a sack because she had lost so much weight since Baba left. The phone rang. My mother answered, and I didn't think it was important because she sounded like she was talking business, but then she handed me the receiver. It was Baba.

"Happy Nowruz," Baba said. "How is the man of the house?"

"When are you coming home?"

"The Red Sox did great. Almost won the Series. Thanks for sending the clippings."

"Mom says it's too dangerous for me to drive."

"Here too. Bad pollution and accidents all the time. The taxis bang into your bumper to push you through a red light."

"You don't have a driver?" I asked.

"No, Reza-Jon. I can drive myself now."

"Are you coming home, then?"

Baba clicked his tongue. I saw him inching forward through the smoggy streets of Tehran, speeding along the highway toward the snow-capped mountains in the distance. I saw the tires of my Playboy ' 67 spinning in the jaws of the compactor, my gold banana seat snapping in two.

I hung up the phone. 